\title{
The Extent of Tunisian Corporate Social Responsibility
}

\author{
Tijani Amara \\ Department of Accounting, Gafsa University, I.S.A.E, Gafsa, Tunisia
}

Email address:

tijani_amara@yahoo.fr

\section{To cite this article:}

Tijani Amara. The Extent of Tunisian Corporate Social Responsibility. Journal of Finance and Accounting. Vol. 4, No. 3, 2016 , pp. 102-110. doi: $10.11648 /$ j.jfa.20160403.12

Received: March 22, 2016; Accepted: April 5, 2016; Published: May 7, 2016

\begin{abstract}
The concept of corporate social responsibility began to attract early reflections from the first decades of the 20th century. The concept of Corporate Social Responsibility is essentially linking to the social theme and the relationship of the company with internal and external partners. It is thus necessary that companies take responsibility for the externalities that are borne by stakeholders. To assess the effectiveness of policies of social responsibility Tunisian firms, we conducted an exploratory study using a questionnaire distributed to a sample of Tunisian company. The researcher divides this work on two parts. The first one discusses the theoretical concepts relating to the social corporate responsibility strategy required. In the second part, the researcher presents the research methodology and the analysis and interpretations of the results generating from a field survey. The results showed that Tunisian firms (our study sample) take into account their social and corporate responsibility in their short and long-term strategies.
\end{abstract}

Keywords: Social Responsibility, Stakeholders, Social Commitments, Discrimination, Environmental Regulations, Strategic Action Plans

\section{Introduction}

With the development of research in the social field, the company is becoming increasingly aware of the potential impact of business activities on the collectivity. The concept of corporate social responsibility began to attract early reflections from the first decades of the 20th century. The term "Corporate Social Responsibility" was present in the theory of business in the 50s. According to Marchetti (2006), this concept is essentially linked to the social theme and the relationship between the company and the environment. Under these conditions, companies assume social commitments alongside their economic functions, production and marketing-oriented obtaining profit. During this period, companies were considering as factors playing an important role in ensuring the social and cultural progress to improve the welfare of civil society. This period is also recognized a strong awareness of the complexity of environmental problems.

On this basis, the stakeholder theory emanates important contributions regarding the social responsibility of the company. Freeman (2002) claims that the only social responsibility of business is to use their resources and engage in activities that aim to increase profits and meet the public purpose. This goal is reflected in the creation of value for the company that included multiple responsibilities overlooked the stakeholders.

It is thus necessary that companies take responsibility for the externalities that are borne by stakeholders. This action allows direct operation of the business to ways socially and economically beneficial for all stakeholders. This orientation helps to develop and expand the social and environmental responsibilities of companies. According to Capron and al (2007), everything can be covered by the social responsibility of the company. This is possible when one considers that, directly or indirectly, little beyond the sphere of economic activity and any economic activity can have unexpected effects on a multitude of actors". Basing on these findings on the importance of social responsibility of business today, we wonder through this research if the Tunisian companies are socially responsible. To judge the effectiveness of social responsibility policies undertaken by the Tunisian companies, the paper is decomposed into two parts. The first will discuss the theoretical concepts related to social corporate responsibility strategy required. In the second part, we present the research methodology followed and the analysis and interpretation of the results generated from a survey field. 


\section{The Corporate Social Responsibility and the Stakeholder Expectations}

\subsection{The Concept of Corporate Social Responsibility}

The term "responsibility" has its origin in the law. For Friedman (1970), corporate responsibility is well defined and bounded. Responsible firm is the one that accepts to face the consequences of its activities. This presupposes knowledge of the effects and to estimate them. Those effects result essentially from negative externalities which are caused by the company such as pollution. According to Delphine (2008), the responsible company is that which reflects the consequences of its actions on itself and its environment. The corporate responsibility becomes an aspect to «achieve commercial success in honoring ethical values, respect for people, communities and the environment" (M Rubinstein, 2006, p. 6). At the Johannesburg conference in 2002, the companies undertake to implement a true "business ethics" of intervening in society as a corporate citizen to influence national and international policy choices (Capron and al 2007).

Corporate citizenship reflects its integration into social life. Its scope is not only economic but also social, cultural and political. This means according to Mousse (1997), that the company should not only takes into account the negative influence but also it should minimize this influence. The concept of social responsibility can be defined in two ways. The first states that the company accepts its social responsibility when it meets all legal and regulatory obligations. The second way considers that these undertakings have a minimum threshold. Therefore, social responsibility must exceed this threshold through voluntary actions. According to Mathews (1993), corporate social responsibility can have three distinct components:

- It may derive from unintended consequences of the company's business;

- It can affect the quality of life inside and outside the company;

- It can raise a civic awareness on the part of the contractor.

Companies according to Carroll (1979), are vital centers of decision and power. Their actions affect the lives of partners in many areas. Based on these principles, Mohamed et al, (2009), confirm that companies are accountable for their actions in a wider sphere than only economic sphere. Carroll (1979) shows that the concept of CSR is all commitments overlooked society. In this context, it defines four kinds of commitments: economic, legal, ethical and human. With the concept of social responsibility of the company presenting by Carroll, it goes well, a reflection on the means of action to reflect on the need to refer to ethics. CSR covers according to Mohamed et al (2009) social and environmental issues. For Allouche (2004) this concept gives rise to an enhanced vision of the traditional term liability that incorporates the constraints of environmental protection and respect for the balance of civil society rules. Social responsibility is the subject of increased attention from many international organizations of very different nature.

Capron et al (2004) argue that the concept of social responsibility of business is based on the scrutiny of the various stakeholders. Thus, convert their stakes in terms of transparency, risk and reputation. The majority of the concepts of social responsibility of business mean the voluntary integration of social and environmental priorities in their business activities. A socially responsible company means not only the one satisfies applicable legal requirements, but also the one that invests "more" into human capital, the environment and relations with stakeholders (European Commission, 2001).

According to Roux (2005), socially responsible investment is part of ethical finance. In this perspective, Erwan (2007) states that the financial performance of the company has become relatively higher because of social investment. However, studies of Griffin and al (1997) on the relationship between social responsibility and financial performance of the company show that 33 studies have established a positive relationship between the two variables. About 20 studies have produced a negative relationship, and 14 studies did not find a significant relationship. Overall, the relationship between social responsibility and financial performance of the company remains relatively unknown. Postel et al (2006) confirm, through their studies of social corporate responsibility and socially responsible investment relationship, the correlation is positive between the two variables.

\subsection{Corporate Social Responsibility and the Stakeholder}

The concept of stakeholders is, according to Pesqueux (2002), is a subject of much debate in the work in the literature of management science. Based on this principle, Capron (2004) argues that the concept of stakeholders is pervasive throughout the literature on corporate social responsibility.

The concept of stakeholder is concerning the parties that have a contractual relationship with the company. Companies may affect decisions or be affect by the actions and decisions of the company. According to Jacques (2002), business decisions largely concern the preservation of sustainable resources by controlling negative externalities and sharing the wealth between present and future generations. In the same meaning Jonas (1990) shows that, the concept of social responsibility of business refers to the responsibility of the present generation to future generations. The following concept was stating by Carroll (1999). According to him, we should take into account the environment and future generations in the economic decisions of the company.

According to Donaldson et al (1995), the stakeholder theory presents the company as cooperative grouping of interests. According to them, the company is not only in relation to its partners but also all the others who are stakeholders whose interests are directly or indirectly affected by the daily business decisions. These decisions have an impact on the economic, social, cultural and environmental heritage. Capron and al (2007) insist that the 
stakeholder theory puts company at the heart of a set of relationships with partners. According to them, these are not only the shareholders, but also others directly or indirectly affected by the activities and decisions of the business people. According to Jenson et al (1976), companies are responsible regardless the internal and external relations. It appears as «the decisive a complex contractual process by which the hypothetical targets people reach equilibrium place." In this context, several researchers point out that the stakeholder theory has serious limits that are somehow manifested by the sometimes-conflicting interests.

Williamson (1985) assumes that shareholders have the main objective of maximizing return on investment by reducing as much as possible the cost of the various transactions, which uses the firm. Caby et al (2005) emphasize that this approach seeks to highlight a point of view held increasingly reducing the social responsibility of the company. That said, Dubingeon (2005) considers that the creation of shareholder value as an end in itself reduces the value of other stakeholders. According to him, the company is a nexus of contracts; it is difficult to limit his vision to one type of them, one between shareholders and managers. The company must study all contracts and how they fit together in conjunction with its strategy. To remedy this problem, Pesqueux et al (2002) and Capron et al (2004) see that it is possible to maximize the interests of each individual. Carroll (1999) distinguishes two types of stakeholders associated with the company. Both internal and external stakeholders are included. Similarly, Salma et al (2003) propose a classification of stakeholders and, depending on their relationship with the company itself:

-The contractual stakeholders such as suppliers, customer's shareholders and employees. - Stakeholders who do not have a direct relationship with the company but who may be affected by activities such as local community associations and public authorities. According to Mathews et al (1991), the consultation and dialogue with stakeholders is a central perspective of the strategic approach to the business. Through this dialogue, the company and stakeholders may enter into a social contract whose main objective is the efficient use of resources while respecting the social stakeholders. This is only possible as Llena et al (2000) points out, when the company provides social and environmental reports.

\subsection{Corporate Social Responsibility and the Stakeholder Expectations}

According to Donaldson and al (1995), the stakeholders are defined by their legitimate interests in the organization. This implies, according to them, that stakeholders are groups and individuals who have legal interests. The stakeholder theory undertakes a theoretical justification for the existence of stakeholders. These fall within two main concepts represented by the legitimacy and power (Andriof and al 2002). Both concepts allow answering the question, which refers to the principle of Freeman (2002), "Who is that and would it really do it?» For the first part of the question, we have already shown the components of stakeholders in direct and indirect relationship with the company. For the second part of the question, referring to the doctrine of social divergence developed by Archer (1996), Friedman and al (2002) view that the relationship between the firm and stakeholders can be, on the one hand, compatible and incompatible with the interests of the company and necessary when it comes to internal stakeholders and secondly, when it comes to contingent external stakeholders.

Table 1. The nature of relationship between firms and stakeholders.

\begin{tabular}{|c|c|}
\hline Stakeholders & Nature of Relationship \\
\hline Shareholders, partners and Direction & Necessary and consistent relations \\
\hline $\begin{array}{l}\text { Unions, employees, government, } \\
\text { customers, suppliers, lenders and } \\
\text { Organization }\end{array}$ & $\begin{array}{l}\text { Necessary but incompatible } \\
\text { relations }\end{array}$ \\
\hline $\begin{array}{l}\text { General public and connecting } \\
\text { organizations in common and } \\
\text { consistent associations }\end{array}$ & Contingent relations \\
\hline Non gouvernental organisations & $\begin{array}{l}\text { Contingent but incompatible } \\
\text { relations }\end{array}$ \\
\hline
\end{tabular}

The nature of the relationship between the company and stakeholders effectively determine the expectations of recent business. These expectations can sometimes be conflicting and, in function of the needs of each individual who has a direct or indirect relationship with the company. The following table summarizes the specific expectations of each stakeholder group:

Table 2. The stakholders expectations.

\begin{tabular}{|c|c|}
\hline $\begin{array}{l}\text { The } \\
\text { stakholders }\end{array}$ & Expectations projected business \\
\hline \multirow{4}{*}{ Shareholder } & Value of the share \\
\hline & Reliability and transparency of information \\
\hline & Environmental and health risk to products and activities \\
\hline & Compliance with environmental and social regulations \\
\hline \multirow{3}{*}{ Direction } & Flexibility and mobility of staff \\
\hline & Motivation of staff \\
\hline & Union membership to the overall company policy \\
\hline \multirow{4}{*}{ Customers } & Price \\
\hline & Innovation and quality \\
\hline & Environmental and health risk products \\
\hline & Compliance with environmental and social regulations \\
\hline \multirow{3}{*}{ Collectivity } & Compliance with environmental and social regulations \\
\hline & $\begin{array}{l}\text { Environmental and health risk to products and activities } \\
\text { Taxes and fees }\end{array}$ \\
\hline & Communication and participation in business life \\
\hline \multirow{4}{*}{ Associations } & Value of the share \\
\hline & Efficiency and transparency of management \\
\hline & Legal liability \\
\hline & Business risks such as pollution and internal security \\
\hline \multirow{3}{*}{ Suppliers } & Enforcement of contracts \\
\hline & Trust and long-term relationship \\
\hline & Social and environmental policy \\
\hline \multirow{3}{*}{ Employees } & Attractive remuneration \\
\hline & Favorable working conditions \\
\hline & Training and Development \\
\hline
\end{tabular}

We note that the majority of individuals constituting the stakeholders are interested in environmental factor. Thus, compliance with environmental and social regulations and 
environmental and health risks associated with products and activities are all factors in the expectations of stakeholders. This explains, in fact, awareness of stakeholders of the role that business can play to protect society. According to Turner et al (2003), the nature of expectations contributes to the optimal allocation of resources and the preservation of the interests of future generations.

\section{The Research Methodology}

To judge the effectiveness of corporate social responsibility, an exploratory study through a questionnaire was conducted among a sample of Tunisian firms. Through this empirical investigation that we can identify and evaluate the policy of the social responsibility of firms. Before presenting the results of this research, we will present successively the context of the study, the sample, the statistical tools used and assumptions of the investigation.

\subsection{The Context of the Study}

Since the $60 \mathrm{~s}$, several movements' awareness was triggering following the harmful effects of human activities, especially those of industrial origin. These waves are expressing by pressures on businesses in order to meet its responsibilities. Gomez et al (2003) identify four groups of sources of green pressures namely regulatory partners, organizational partners, community partners and the media. According to the author, business leaders emit an effective CSR strategy when the pressures come from all partners. According to Gnandi et al (2006), these pressures vary in intensity depending on the country, the industry and even firm. For each country, the issue of social responsibility is in particular aspects. Thus, it does not present in Tunisia, the same characteristics as those that might be founding in other countries. The issue of social responsibility in Tunisia arises in very acute terms for several reasons including the phenomenon of unemployment. Although the Tunisian State provides guaranties to companies that take their social responsibilities to its partners, taking into account an effective policy of social responsibility in their strategies remains weak and sometimes negligible few companies operating in the industrial sector in particular. In addition, the relatively low pressure of the community on companies seeking employment because the unemployment rate is very high in Tunisia.

\subsection{Presentation of the Sample}

The statistical data in the portal of Tunisian industry have about 5000 companies of all sizes with a workforce greater than or equal to 10 employees in 2775 , which are totally exporting enterprises. For the purposes of our research, we selected a sample of firms belonging to different sectors witch the phenomenon of social responsibility applies to all companies regardless of the nature of activities. The majority of surveyed firms are classifyied us the top 500 companies in Tunisia in 2010 .
The questionnaire was first tested to verify its validity and possible amendments. Therefore, it was administering by telephone to a company that has tested the questions and some twenty modifications were made to the questionnaire for a better understanding of its contents. The final questionnaire was administered to 300 companies (via direct contact and e -mail) belonging to different regions of the country. We distributed one copy per company. The number of questionnaires collected was 130 copies representing a rate of about $43 \%$.

\subsection{The Statistical Tools Used}

Tools and statistical methods are necessary for the purposes of the analysis to be conducted. We opted for the SPSS 19.0 software for processing the questionnaire data. We used principal components analysis to test the hypotheses of the research. From the perspective of interpreting factors, analysis suggests major components; we perform a linear regression analysis to explain a quantitative variable by another quantitative variable. Gains and losses are used to verify the contribution of each exogenous variable in the variation of the endogenous variable. This may be checked through the discriminate analysis that demonstrate the relationship between a dependent variable and a nominal set of explanatory variables (quantitative) of proportion or interval.

At the global level, the coefficient of determination $\mathrm{R}^{2}$ will explain the share of variable $\mathrm{Y}$ explained by the variation of $\mathrm{X}$. Then the Fisher test allows us to assess the significance of the results.

\subsection{The Conceptual Framework of the Research}

Adopting an effective policy of social responsibility, involves changes in attitudes, values and visions and a demonstration of sustainable intention. Knowing the determinants of social responsibility will facilitate, indeed, the establishment of an effective social strategy. The majority of theoretical works that focus on the study of an effective policy of social responsibility refers to the theory of planned behavior Ajzen $(1987,1991)$. This theory states, according to Ajzen (1991), that the intention to adopt a behavior is a direct determinant of the action. Thus, to predict the behavior of individuals by identifying individual and contextual factors that determine it aims. According to Ajzen (1991), predicting the behavior should be through three components namely, attitudes associated with the behavior, subjective norms and perceptions of behavioral control. As part of our research, it seems to us that it is appropriate to adopt the theory of planned behavior as a theoretical framework. Tunes (2001), for example, confirms that the theory of planned behavior has been used with great success for the basic and empirical research.

\subsection{Description of the Assumptions of the Study}

We recall that the main objective of this study is to evaluate the policies of Tunisian companies in CSR, as trigger cognitive processes, leading to substantially 
consistent and relevant social and environmental actions.

Our hypotheses were defined according to the model of the theory of planned behavior (Ajzen, 1987, 1991) by adapting the variables of interest and study context. Table 3 describes the conceptual model that was tested.

Table 3. Structure of the research hypotheses.

\begin{tabular}{lll}
\hline \multicolumn{2}{l}{ Tunisian enterprises adopt effective social responsibility policies (Lafontaine, 2006) } & Step 2 \\
\hline H1 & H2 & H3 \\
\hline $\begin{array}{l}\text { Tunisian firms adopt strategic action plans } \\
\text { promoting social responsibility }\end{array}$ & $\begin{array}{l}\text { Tunisian companies have social and } \\
\text { societal impacts reflecting their } \\
\text { responsible behavior }\end{array}$ & $\begin{array}{l}\text { Tunisian enterprises have undertaken internal } \\
\text { and external actions reflecting their social } \\
\text { responsibilities }\end{array}$ \\
Attitudes associated to the behavior & Subjective standards & Perceptions of behavioral control \\
\hline
\end{tabular}

According to the model of planned behavior adopted, the determinants of social responsibility are the order of three key variables (Table 3 ):

- Attitudes associated with behaviors depend on strategic action plans. (Martinet et al, 2004);

- Subjective norms are manifested by social and societal impact of the company on its environment (Marilena, 2008);

- Perceptions of behavioral control are associated with the degree of firms responding to their social responsibilities (Gendron, 2004);

We want to test this hypothesis and identify the relative contribution of each of these variables to the explanation of social responsibility. The three sub-hypotheses are:

H1: Tunisian firms adopt strategic action plans promoting social responsibility

H2: Tunisian companies have social and societal impacts reflecting their responsible behavior

H3: Tunisian companies have undertaken internal and external actions reflecting their social responsibilities Likert scale with three positions is intended to measure corporate social responsibility us follow:

- For the attitudes associated to behaviors «the strategic action plans for social responsibility" they were measured by 10 items assessing strategy in corporate social responsibility.

- To measure subjective norms «social and societal impacts" we used 11 items that describe the influences exerted by the company on its internal and external environment.

- As for the «degree of reaction of firms towards their social responsibilities" we measured using 11 items that describe the main actions implemented by companies reflecting their social responsibilities.

\section{Analysis and Interpretation of Results}

To ensure a scientific rigor, we have conducted to test the reliability of the measurement scale. Reliability refers to the degree of stability of a measure for an indefinite time and some are interviewing. During the first step, we verified that the selected scales were reliable. The evaluation scales can be performing by using the calculation of Cronbach's alpha. According to Evrard et al (2003), an alpha between 0.6 and 0.8 is acceptable for an exploratory study.

To test our hypotheses, we proceeded by step. Validating the assumption was made by regressing the variable measuring "Social Responsibility" in its three determinants. However, before checking this assumption, it seems necessary to test first the other three hypotheses whose validation required, first, the principal component analysis prior, to reduce the amount of gathering the information in various determinants measured fewer factors.

\subsection{The Strategic Action Plans Promoting Social Responsibility}

The principal component analysis is used is to extract two factors explaining the strategic action plans promoting social responsibility among Tunisian companies. These factors explain about $76 \%$ of the total variance and are as follows:

- Factor 1: «Strategic Core Commitments»

- Factor 2: «Strategic Environmental Actions»

To identify the significant relationships between exogenous variables (retained factors) and endogenous (The strategic action plans), we relied on multiple regression analysis. Table 3 presents statistics testing the relationship between strategic plans and the two factors identified by the ACP.

Table 4. Descriptive statistics for reporting the adjustment concerning the hypothesis H1.

\begin{tabular}{|c|c|c|c|c|c|c|c|c|c|}
\hline \multirow{2}{*}{ Model } & \multirow{2}{*}{$\mathbf{R}$} & \multirow{2}{*}{ R square } & \multirow{2}{*}{$\begin{array}{l}\text { R square } \\
\text { adjusted }\end{array}$} & \multirow{2}{*}{$\begin{array}{l}\text { standard Error of' } \\
\text { estimation }\end{array}$} & \multicolumn{5}{|l|}{ Statistics } \\
\hline & & & & & R square Change & F Change & df1 & df2 & Sig. F Change \\
\hline M1 & 0,558 & 0,546 & 0,522 & 0,4218 & 0,523 & 56,680 & 10 & 119 & 0,000 \\
\hline
\end{tabular}

The regression results indicate, for the reference population, a good correlation between the strategic action plans and selected factors. The intensity of the relationship results in a correlation coefficient $\mathrm{R}$, the value is $55.8 \%$. The adjusted R2 has an acceptable score 0.522 . This result indicates that the model returns $52.2 \%$ of the variation expressed in the baseline.

To assess the goodness of fit of the regression, we used the Fisher's F test. The critical value of F, the threshold $\alpha=0.01$ for 10 and 119 degrees of freedom is equal to 6.31 . The 
calculated F $(56.680$, sig. $=0.000)$ and significantly higher, we can conclude that the quality of the fit provided by the regression is significant. There is therefore, a significant dependence between the strategic action plans and the related factors retained by the ACP.

To assess the contributions of each of these to the overall explanation of the model, we calculated the values of the partial multiple regression coefficients whose values are reported in Table 5.

Examination of values for adjustment coefficients indicates that the factor "Commitments fundamental responsibility" explains almost $30 \%$ of the variation of strategic action plans. The factor, "Strategic Environmental Actions ", it contributes $43 \%$ to the overall explanation of the model. We have thus, from the regressions already advanced, confirmed the existence of a significant and positive effect of the two explanatory factors used (Core Commitments responsible and strategic environmental Shares) on the endogenous variable "The strategic action plans."

Table 5. Values of the partial coefficients for the first adjustment model (M1).

\begin{tabular}{|c|c|c|c|c|c|c|}
\hline \multirow{2}{*}{\multicolumn{2}{|c|}{ Model M1 }} & \multicolumn{2}{|c|}{ Unstandardized coefficients } & \multirow{3}{*}{$\begin{array}{l}\text { Standardized coefficients } \\
\text { Beta } \\
0,380\end{array}$} & \multirow{3}{*}{$\begin{array}{l}\mathbf{t} \\
6,642\end{array}$} & \multirow{3}{*}{$\begin{array}{l}\text { Sig. } \\
0,000\end{array}$} \\
\hline & & \multirow{2}{*}{$\begin{array}{l}\text { B } \\
0,308\end{array}$} & \multirow{2}{*}{$\begin{array}{l}\text { Erreur Std. } \\
0,027\end{array}$} & & & \\
\hline & Fundamental responsible commitments & & & & & \\
\hline & Strategic environmental actions & 0,431 & 0,027 & 0,438 & 6,067 & 0,000 \\
\hline
\end{tabular}

\subsection{Social Impacts and Societal Behaviors Reflecting the Responsibility of Firms}

The principal components analysis revealed a four-factor solution $(82.50 \%$ of total variance): - Factor 1: "The lute against discrimination."

- Factor 2: "The compliance with environmental regulations."
- Factor 3: "The social and societal engagement."

For our study, the dependent variable is the social and societal impacts reflect responsible behavior and the explanatory variables are those identified and agreed by the ACP. The test of statistical regression whose basic characteristics are given in Table 6 provides information on the quality of multiple adjustment retainers (model M2).

Table 6. Descriptive statistics for reporting the adjustment concerning the hypothesis HP2.

\begin{tabular}{|c|c|c|c|c|c|c|c|c|c|}
\hline \multirow{2}{*}{ Model } & \multirow{2}{*}{$\mathbf{R}$} & \multirow{2}{*}{$\begin{array}{l}\text { R } \\
\text { square }\end{array}$} & \multirow{2}{*}{$\begin{array}{l}\text { R square } \\
\text { adjusted }\end{array}$} & \multirow{2}{*}{$\begin{array}{l}\text { standard Error } \\
\text { of' estimation }\end{array}$} & \multicolumn{5}{|l|}{ Statistics } \\
\hline & & & & & R Square Change & F Change & dl1 & d12 & Sig. F Change \\
\hline M2 & 0,583 & 0,567 & 0,559 & 0,3371 & 0,552 & 65,379 & 10 & 117 & 0,000 \\
\hline
\end{tabular}

The test of the regression coefficient reveals a strong correlation $(\mathrm{R}=58.3 \%)$ between the dependent variable the social and societal impacts reflecting the responsible behavior and the factors that explain. The expression of this relationship is expressed by a correlation coefficient R2 of $56.7 \%$. The adjusted R2 has an acceptable score 0.559, indicating that the model explains almost $56 \%$ of the variation expressed in the baseline. To assess the goodness of fit of the regression, we used the Fisher test that can tell from Patton (2001) if, for $\alpha$ risk considering, multiple R2 is significantly different from 0 . The critical value of $F$, the threshold $\alpha=0.01$ for 10 and 117 degrees of freedom is equal to 7.339 . The calculated $\mathrm{F}(55.739$, sig. $=0.00)$ and significantly higher, we can confirm that the quality of the fit provided by the regression is significant. There is, therefore, a significant dependence between the social and societal impacts reflect responsible behavior and the three factors representing its determinants. The analysis by multiple regressions used in the explanation of changes in social and societal impacts reflecting the responsible behavior is presented in Table 7.

Table 7. Model Values of the partial coefficients for the second adjustment model (M2).

\begin{tabular}{llllll}
\hline \multirow{2}{*}{ Model M2 } & \multicolumn{2}{l}{ Unstandardized coefficients } & \multicolumn{2}{l}{ Standardized coefficients } & \multirow{2}{*}{ Sig. } \\
\cline { 2 - 5 } & B & Erreur Std. & Beta & 6,642 & 0,000 \\
\hline The fight against discrimination & 0,332 & 0,021 & 0,398 & 6,067 & 0,000 \\
Compliance with environmental regulations & 0,179 & 0,021 & 0,363 & 0,348 & 0,000 \\
The social and societal commitment & 0,161 & 0,021 & 0,260 & 4,380 \\
\hline
\end{tabular}

Examination of the regression coefficients indicates that the factor "The fight against discrimination" best explains the social and societal impacts reflect responsible behavior (33.2\%). The factor "Meeting environmental regulations" contributes $17.9 \%$ to the overall explanation of the model. The social and societal commitment participates with $16.1 \%$.

There is thus a positive and significant correlation between, on the one hand, the variable representing the social and societal impacts reflecting the responsible behavior and, on the other hand, the variables that explain namely the fight against discrimination, compliance with environmental regulations and social and societal commitments. Accordingly, the second hypothesis of our research, stating that Tunisian firms have social and societal impacts 
reflecting their responsible behavior can be accepted.

\subsection{Strategic Actions}

By applying PCA to the items describing the main strategic actions that can be undertaking by companies, the analysis reveals two factors that explain nearly $80 \%$ of the total variance. These factors are:

- Factor 1: «Contributing shares intra -firm relations»
- Factor 2: «Contributing shares relations with stakeholders»

In our study, the dependent variable represents the strategic actions taken by firms and the explanatory variables are those identified and retained by the ACP (promoting intra -company shares and shares promoting relations with stakeholder relations). The test regression (model M3) is presenting in Table 8.

Table 8. Descriptive statistics for reporting the adjustment concerning the hypothesis HP3.

\begin{tabular}{|c|c|c|c|c|c|c|c|c|c|}
\hline \multirow{2}{*}{ Model } & \multirow{2}{*}{$\mathbf{R}$} & \multirow{2}{*}{$R$ square } & \multirow{2}{*}{$\begin{array}{l}\text { R square } \\
\text { adjusted }\end{array}$} & \multirow{2}{*}{$\begin{array}{l}\text { standard Error } \\
\text { of' estimation }\end{array}$} & \multicolumn{5}{|l|}{ Statistics } \\
\hline & & & & & R Square Change & F Change & dl1 & $\mathrm{dl} 2$ & Sig. F Change \\
\hline M3 & 0,674 & 0,652 & 0,649 & 0,266 & 0,651 & 258,547 & 10 & 117 & 0,000 \\
\hline
\end{tabular}

The test of the regression coefficient reveals a strong correlation $(\mathrm{R}=67.4 \%)$ between the endogenous variable and two explanatory factors. The expression of this relationship is expressing by a correlation coefficient R2 of $65.2 \%$. The adjusted R2 has an acceptable score of 0.64 . This result indicates that the model reproduces almost $65 \%$ of the variation expressed in the baseline. The critical value of $\mathrm{F}$, the threshold $\alpha=0.01$ for 10 and 117 degrees of freedom is equal to 7.339 . The calculated $\mathrm{F}(258.547$, sig. $=0.000)$ is significantly higher. This allows us to confirm that the quality of the fit is significant restraint. There is therefore a significant dependence between, on the one hand, the strategic actions taken by companies on the one hand, the predisposing factors explaining the actions taken corporate social responsibility on the other hand.

Table 9. Values of the partial coefficients for the third adjustment model (M3).

\begin{tabular}{llll}
\hline \multirow{2}{*}{ Model 3 } & \multicolumn{2}{l}{ Unstandardized coefficients } & \multicolumn{2}{l}{ Standardized coefficients } \\
\cline { 2 - 4 } Sig. & B & Erreur Std. & Beta \\
\hline Relations inter-entreprises & 0,442 & 0,020 & 0,758 \\
Relations with stakholders & 0,278 & 0,020 & 0,325 \\
\hline
\end{tabular}

As indicated in the previous table, the values of the partial regression coefficients give the contributions of each of the exogenous variables to the overall explanation of the model. We note that it is the axis «inter-firm relationships" that best explains the strategic actions promoting companies social responsibility (42.2\%). The factor "relations with stakeholders" contributes with $27.8 \%$ to the overall explanation of the model.

Thus, and according to the regressions already advanced, we can confirm the existence of a significant and positive effect of selected factors on the endogenous variable «promoting the actions undertaken social responsibility».

We can therefore confirm the third hypothesis of our research advancing Tunisian companies have undertaken internal and external actions reflecting their social responsibilities.

\subsection{Checking the Assumption}

To determine the perceived ability of each factor used in explaining variations in the basic assumption "Tunisian companies adopt effective policies on social responsibility" and assumptions in assessing the social responsibility, we have used analysis by multiple regression technique. The results of the regression are as follows:

Table 10. Values of the partial coefficients for the fourth adjustment model (M4).

\begin{tabular}{|c|c|c|c|c|c|}
\hline \multirow{2}{*}{ Model } & \multicolumn{2}{|c|}{ Unstandardized coefficients } & \multirow{2}{*}{$\begin{array}{l}\text { Standardized coefficients } \\
\text { Beta }\end{array}$} & \multirow{2}{*}{$\mathbf{t}$} & \multirow{2}{*}{ Sig. } \\
\hline & B & Erreur Std. & & & \\
\hline $\begin{array}{l}\text { Tunisian firms adopt strategic action plans promoting social } \\
\text { responsibility }\end{array}$ & 0,352 & 0,026 & 0,387 & 6,426 & 0,000 \\
\hline $\begin{array}{l}\text { Tunisian companies have social and societal impacts reflecting } \\
\text { their responsible behavior }\end{array}$ & 0,282 & 0,026 & 0,274 & 4,088 & 0,000 \\
\hline $\begin{array}{l}\text { Tunisian enterprises have undertaken internal and external actions } \\
\text { reflecting their social responsibilities }\end{array}$ & 0,376 & 0,026 & 0,354 & 6,228 & 0,000 \\
\hline
\end{tabular}

As indicated in the previous table, the values of the partial regression coefficients give the contributions of each of the exogenous variables to the overall explanation of the model. Thus, the axis " internal and external business activities" explains more the corporate social responsibility (37.6\%). The axis «strategic action plans promoting social responsibility" contributes $35.2 \%$ to the overall explanation of the model. Finally, the axis " internal and external actions" contributes $28.2 \%$ to the explanation of the overall model. We can therefore confirm the basic hypothesis of our research stating, «The Tunisian companies adopt effective policies on social responsibility." 


\section{Conclusion}

According to the study, Tunisian companies promote social responsibility and thus meet the expectations of different stakeholders. This is justified is based on the results released, highlighting a social conscience more or less strong and adoption of strategic actions reflecting the social behavior of companies. The results showed that Tunisian firms (our study sample) take into account their social and corporate responsibility in their short and long-term strategies and in accordance with the expectations of internal and external stakeholders for the implementation work conducive to the implementation of social policy conditions. Working more on the axes studied, we believe that public authorities and non-governmental organizations can greatly improve the feasibility of social practices.

However, it is important to note that social practices remain for a large part of businesses, face a threat to growth and wealth creation. For some leaders, achieving both good performance and social policy reflecting the social behavior of the company is difficult if not impossible to achieve at least on short-term basis.

\section{References}

[1] Ajzen, I. (1991). The theory of planned behavior. Organizational and Human Decision Processes 50, 179-211.

[2] Allouche J., F., Huault, I. (2004). Information des actionnaires et Rapports RSE. Communication Journée du GreGor/IAE de Paris - 26.11.03, Gouvernance et Développement Durable.

[3] Andriof, J., Waddock, S. (2002). Stakeholder thinking: Theory, responsibility and engagement. Sheffield, Greenleaf, p. 19-42.

[4] Caby, J., Hirogoyen, G. (2005). Histoire de la valeur en Finance d'entreprise. Article non publié.

[5] Capron M. et Quairel-Lanoizelée F. (2004). Mythes et Réalités de l'Entreprise Responsable. Revue de l'Organisation Responsable, $n^{\circ} 3$, pp 18-27, Paris.

[6] Capron, M. et Quairel-Lanoizelee, F. (2007). La responsabilité sociale d'entreprise. Coll. Repères, La découverte édition.

[7] Carroll A. (1979). Three-dimensional conceptual model of corporate social performance. Academy of Management Review, $n^{\circ} 4$.

[8] Carroll, A. (1999). Corporate Social Responsibility. Business \& Society, vol. 38 , no 3

[9] Delphine, G.-A. (2008). La perception du dirigeant de PME de sa responsabilité sociale: une approche par la cartographie cognitive. Thèse présentée à la Faculté des sciences économiques et sociales, université de fribourg, Suisse.

[10] Donaldson T. \& Preston L. E. (1995). The stakeholder theory of the corporation: concepts, evidence and implications. Academy of Management Review, vol. 20, n 1, p. 65-91.

[11] Dubigeon, O. (2005). Mettre en pratique le développement durable. Quels processus pour l'entreprise responsable?. $2^{\mathrm{eme}}$ édition, Edition Village mondial, Paris/Pearson Education France, pp 24-25.
[12] Erwan, Harscoet. (2007). Développement d'une comptabilité environnementale orientée vers la création de valeur: l'application à un investissement de prévention des pollutions. Thèse de doctorat présentée à l'Ecole supérieure nationale d'Arts et Métiers, Chambéry France.

[13] Evrard, Y, Y, Pras, B et E, Roux, E. (2003). Market: Etudes et recherches en marketing. Paris, Editions Dunod.

[14] Freeman, R. E., Phillips R. A. (2002). Stakeholder theory: a libertarian defense. Business Ethics Quarterly, 12(3), p. 1-21.

[15] Friedman, M., (1970). The social responsibility of business is to increase its profits. New York Times Magazine, September 13, p. 32-33, 122, 124, 126.

[16] Gendron, C. (2004). La responsabilité sociale d'entreprise dans la PME; option marginale ou enjeu vital ? 7ème Congrès International Francophone en Entrepreneuriat et PME 27, 28 et 29 Octobre, Montpellier.

[17] Gnandi, K., Tchangbedji, G (2006). The impact of phosphate Mine tailing on the Bioaccumulation of Heavy Metals in Marine Fish and Crustacean from the Coastal Zone at Togo. International Journal of Mine Water and Environment pp 5662 .

[18] Gomez P. Y. (2003). La nature actionnariale: quelques points de repère. La responsabilité sociale des entreprises: Etudes et documents, Edition réseaux ANACT.

[19] Griffin, J., John, M. (1997). The corporate social performance and corporate financial performance debate: Twenty-five years of incomparable research. Business and Society Vol. 39 no $1,5-31$.

[20] Jacques- Jean Rosé (2002). Responsabilité sociale de l'entreprise. De Boeck, 1ère édition, Bruxelles, pp. 215-238.

[21] Jensen, M., Meckling, W. (1976). Theory of the Firm: Managerial Behavior, Agency Costs and Ownership structure. Journal of Financial Economics, Vol. 3, pp. 305-360.

[22] Jonas H. (1990). Le Principe de Responsabilité. Traduit par Greisch, Paris, le Cerf.

[23] Llena, et Moneva. (2000). Environmental disclosures in the annual reports of large companies in Spain. European Accounting Review. Vol. 9, pp, 7-29.

[24] Marchetti, S. (2006), L'informativa socio-ambientale nel sistema aziendale. Strumenti Comunicazionali, Bari, Cacucci Editore. Traduit par Marilena (2008).

[25] Marilena, M. (2008). Social Responsibility and Environmental Ethics: Elements of the Ecological Culture in 21st Century Organization: A study of Romanian companies. MPRA, Munich Personal Repec Archive.

[26] Martinet, A., Renaud, E., (2004). Stratégies d'entreprises et écologie. Paris: Economica.

[27] Mathews, M. R. (1993). Socially responsible accounting. London: Chapman Hall.

[28] Mathews, M. R., Perera, M. (1991). Accounting theory and development. London, Chapman and Hall.

[29] Mohamed M'HAMDI et Sabah TRID, (2009). La responsabilité sociale de l'entreprise au Maroc: une étude empirique auprès des petites et moyennes entreprises de la région de Fès Boulemane. 11eme journées scientifiques de réseaux Entrepreneuriat AUF. 
[30] Moussé J. (1997). Ethique et profit aujourd'hui. Revue française de gestion, $\mathrm{n}^{\circ} 112$, pp, 52-58.

[31] Patton, M. Q. (2001). Qualitative Research and Evaluation Methods. Newbury Park: Sage Publications.

[32] Pesqueux Y. (2000). Le gouvernement de l'entreprise comme idéologie. Ellipses, Paris.

[33] Postel, N., Rousseau, S., Sobel, R. (2006). La responsabilité sociale et environnementale des entreprises. Economie appliquée LIX.

[34] Roux, M., (2005). Finance éthique: structures, acteurs et perspectives en France. Université Paris 13, CEPN, actes du $3^{\text {ème }}$ congrès de l'ADERSE sur la responsabilité sociale de l'entreprise, Lyon.

[35] Rubinstein M. (2006). Le développement de la responsabilité sociale de l'entreprise: une analyse en termes d'isomorphisme institutionnel. Revue d'Economie Industrielle, 113, pp, 83105 .
[36] Salma, D. A; Pesqueux, Y (2003). La théorie des parties prenantes. Atelier de développement durable de l'AIMS, Anger.

[37] Tchaman, J.-P. et Ch. Estay (2004). La pratique de la responsabilité sociale et ses implications dans l'entreprise. Gestion 2000, juillet-août., pp, 31-47.

[38] Tounes A. (2001). Une modélisation théorique de l'intention entrepreneuriale. VIIèmesJournées Scientifiques du Réseau Entrepreneuriat de l'AUF, "Formation et entrepreneuriat", Île Maurice, 4 au 7 juillet, pp, 111-123.

[39] Turner, K. R., Pearce, W. D. (2003). Economia ambientale. Bologna, Il Mulino.

[40] Williamson. O. E. (1985). The Economic Institutions of Capitalism. Free Press, NEW YORK. 